\title{
Research on Influencing Factors of the Leverage Ratio of Non-financial Enterprises in the GBA
}

\author{
Shihong Zeng ${ }^{1,2}$, Fan $\mathrm{Li}^{1,2, *}$ and Zhen Zhong,"*
}

\begin{abstract}
This paper studies the factors influencing the leverage ratio of non-financial enterprises in the Guangdong, Hong Kong and Macao Greater Bay Area (GBA) from 2007 to 2017. On the whole, the leverage ratio of non-financial enterprises in the greater bay area is not high. From the perspective of ownership, state-owned enterprises have a higher leverage ratio than non-state-owned enterprises. The leverage ratio differs significantly across industries. From the regional perspective, before 2008, enterprises in Macao had the lowest leverage ratio, and those in Guangdong had the highest. In recent years, the corporate leverage ratio has tended to be similar among the enterprises in Guangdong, Hong Kong and Macao. Corporate profitability is the most important micro-level factor affecting the leverage ratio, and economic growth has the most significant direct impact on the leverage ratio of non-state-owned enterprises. In addition, the economic growth rate, the M2 growth rate and policy uncertainty have a clear indirect impact on the leverage ratio.
\end{abstract}

JEL classification numbers: G11, G24, G34.

Keywords: Guangdong-Hong Kong-Macao Greater Bay Area, Leverage ratio, Influencing factors, Two-way fixed effects.

\footnotetext{
* Corresponding authors

${ }^{1}$ Applied Economics Department, College of Economics \& Management, Beijing University of Technology, Beijing 100124, China.

${ }^{2}$ Finance and Economics Development Research Center, College of Economics \& Management, Beijing University of Technology, Beijing 100124, China.

${ }^{3}$ Department of Development Strategy and Regional Economic Research, Development Research Center of the State Council,Beijing,100010, China.
} 


\section{Introduction}

The Guangdong-Hong Kong-Macao Greater Bay Area is a world-class city cluster built by comparison with the bay areas of New York, San Francisco and Tokyo. It bears the important responsibility of revitalizing the Chinese economy, supporting the construction of the "One Belt and One Road" and participating in global competition. On February 18, 2019, the Communist Party of China (CPC) Central Committee and the State Council issued the outline of the development plan for the Guangdong-Hong Kong-Macao Greater Bay Area. The outline calls for "giving full play" to the capital markets and financial services functions of Hong Kong, Macao, Shenzhen and Guangzhou and cooperating to build diversified, international and trans-regional investment and financing systems for scientific and technological innovation. We will vigorously expand direct financing channels and build financial support platforms for scientific and technological innovation by relying on regional equity trading markets. Therefore, scholars are interested in how to make full use of the market and geographical advantages of the Guangdong-Hong Kong-Macao Greater Bay Area to build a modern investment and financing platform.

The leverage ratio is an important indicator reflecting the investment and financing structure of enterprises and the overall financial risk. Since the financial crisis in 2007, the leverage ratio of non-financial enterprises in Guangdong, Hong Kong and Macao has been increasing. According to data from the national balance sheet research centre (CNBS), from 1993 to 2008, the leverage ratio of the non-financial corporate sector in China fluctuated between $80 \%$ and $100 \%$, while that in Hong Kong fluctuated between $90 \%$ and $140 \%$. After 2008, the leverage ratio of nonfinancial enterprises in China began to increase year by year. Leverage in the nonfinancial corporate sector has been rising since a brief decline in 2011, peaking at $161.4 \%$ in the first quarter of 2017. Leverage in Hong Kong's non-financial corporate sector has grown even faster, peaking at $234.70 \%$ in the first quarter of 2018.

In recent years, the downward pressure on China's economy has intensified, the leverage ratio of non-financial enterprises has remained high, and the hidden risks have become increasingly apparent. In January 2016, the central economic work conference put forward the supply-side structural reform plan, in which "deleveraging" was listed as one of the five core tasks of China's economic reform. As a highly open and internationalized city group in China, the Guangdong-Hong Kong-Macao Greater Bay Area plays an important role in the revitalization of China's economic construction. In 2018, its economic aggregate exceeded 10.8 trillion yuan, accounting for approximately 12\% of China's GDP. The study of "deleveraging" in the greater bay area of Guangdong, Hong Kong and Macao can provide guidance for government departments to better control the leverage ratio. The influencing factors must be clarified in order to control the leverage ratio of non-financial enterprises. Based on this background, this paper studies the influencing factors of the leverage ratio of non-financial enterprises in the Guangdong-Hong Kong-Macao Greater Bay Area. 


\section{Literature review}

Previous studies have explained the factors affecting the leverage ratio mainly based on the theories of tradeoff, pecking order, adverse selection and balance sheet recession. These factors can be divided into micro factors and macro factors.

\subsection{Literature review on micro-influencing factors}

\subsubsection{Profitability}

According to the pecking order theory, enterprises with good profitability have more retained earnings, so when they need financing, they first turn to internal financing and thus have a lower leverage ratio. According to the tradeoff theory, under market conditions with financial friction, the stronger the profitability of an enterprise is, the easier it will be for the enterprise to obtain low-cost debt financing, thus leading to a higher leverage ratio. Tan et al. [1] believed that corporate profitability is negatively correlated with the leverage ratio.

Xiao and Zou's [2] findings supported this negative correlation and suggested that companies with strong profitability usually have less debt. Through further research, they found that this is because listed companies in China have a strong preference for equity financing, and companies with strong profitability are more likely to obtain funds from the stock market. The empirical results of Su and Zeng [3] showed that the profitability of enterprises, measured by ROA, was negatively correlated with the asset-liability ratio.

\subsubsection{Tangibility}

According to the tradeoff theory, the higher the ratio of tangible assets is, the more assets can be mortgaged in debt financing and the higher the leverage ratio. According to the adverse selection theory, tangible assets account for a relatively high proportion of enterprises assets, which reduces the cost to creditors of obtaining enterprise information and is therefore conducive to the convenient realization of debt financing, so the leverage ratio of enterprises is relatively high. Xiao and Zou [2] verified the above theory by finding that companies with a high proportion of tangible assets generally resort to more debt.

\subsubsection{Enterprise scale}

According to the static tradeoff theory, the larger an enterprise is, the stronger its debt financing ability and the higher its leverage ratio will be. However, according to the pecking order theory, the larger an enterprise is, the lower the information asymmetry and equity financing cost will be, which leads to a preference for equity financing and a lower leverage ratio. Xiao and Zou [2] believed that the relationship between company size and leverage ratio was consistent with the expectation of the static tradeoff model; that is, company size is positively correlated with leverage ratio. Su and Zeng [3] used the natural logarithm of enterprise operating income after adjusting for inflation to measure the scale of enterprises and concluded that the larger the scale of enterprises is, the higher the leverage ratio will be. 


\subsubsection{Growth opportunity}

Xiao and Zou [2] found that companies with more growth opportunities generally have lower leverage ratios, which is consistent with the tradeoff theory. Belkhir et al. [4] used companies from the Middle East and North Africa as research samples and measured the growth capacity by the ratio of equity market value and book value of debt to total assets. The study found that, except for enterprises in some countries, the growth capacity of companies was negatively correlated with the leverage ratio. Su and Zeng [3] used Tobin's Q to measure the development opportunity of the company and found that the development prospect of a company was directly proportional to its external capital. According to the tradeoff theory, enterprises with good growth opportunities tend to prefer equity financing because high growth opportunities often mean an increase in the risk and cost of financial distress to enterprises, and enterprises tend to use stock market financing to reduce their debt financing risks. However, the pecking order theory holds that high growth opportunities are accompanied by aggravated information asymmetry and increased equity financing cost, and enterprises prefer debt financing, which increases the leverage ratio.

\subsubsection{Tax shield}

Su and Zeng [3] measured the company's non-debt tax shield by comparing the accumulated depreciation, unamortized expenses, deferred assets, and start-up expenses to the total assets. They found that the less a company gains from interest tax deduction, the less willing it will be to expand debt, and the non-debt tax shield of the company is negatively correlated with the leverage ratio. Liang et al. [5] found that the tax shield effect of debt interest was negatively correlated with the leverage ratio.

\subsubsection{Corporate ownership}

In China, state-owned enterprises have close links with banks, which can reduce the cost to banks of evaluating their credit qualifications; on the other hand, they have implicit government guarantees, which makes it easier for them to borrow money and leads their leverage ratio to be higher than that of non-state-owned enterprises. Belkhir et al. [4] found that the institutional quality of a country has a crucial impact on the decision-making concerning enterprise capital structure. Liang et al. [5] found that the state-owned holding ratio of listed companies in China was positively correlated with the leverage ratio. However, Lu et al. [6] confirmed that high debt is not the same as excessive debt and that state-owned enterprises have a lower possibility of excessive debt.

\subsubsection{Industry}

Through empirical analysis of Chinese listed companies, Guo and Sun [7] found that industry is an important factor affecting the debt ratio of enterprises and that the capital structure of listed companies in the same industry is stable and 
significantly different from that in other industries. Tan et al. [1] conducted an empirical study using the median leverage ratio of the industry and found that the corporate leverage ratio was closely related to industry characteristics. Li and Islam [8], Köksal and Orman [9] found that industry factors had an important impact on the leverage ratio.

\subsection{Literature review of macrolevel influencing factors}

\subsubsection{Economic growth}

Chen and Xiong [10] believed that an important reason for the increase in corporate debt pressure is the decline of China's economic growth rate. Su and Zeng [3] found that the company's debt ratio was closely related to the macroeconomic cycle. When the macroeconomy improved, the corporate debt ratio fell; when it deteriorated, the debt ratio increased. Halling et al. [11] also verified the counter-cyclical characteristics of the enterprise leverage ratio.

\subsubsection{Inflation}

According to Koksal and Orman [9], corporate liabilities increase with inflation. However, Liu et al. [12] found that the inflation rate has a significant "deleveraging" effect in the short and medium terms. Tan et al. [1] elaborated on the indirect influence of the inflation rate on the leverage ratio and believed that an increase in the inflation rate would weaken the effect of the non-debt tax shield and size on the leverage ratio of state-owned enterprises, while the opposite was true for non-stateowned enterprises.

\subsubsection{Economic policy uncertainty}

The economic policy uncertainty index, compiled by Scott R. Baker, Nicholas Bloom and Steven J. By, can be used to reflect the economic and policy uncertainty of the world's major economies. Rao et al. [13] believed that the increase in economic policy uncertainty will significantly reduce enterprise investment and increase the investment efficiency. Ji et al. [14] found that an increase in economic policy uncertainty would lead to an increase in the leverage ratio of state-owned enterprises and a decrease in the leverage ratio of non-state-owned enterprises, and this difference was more obvious in regions with strong financial repression.

\subsubsection{M2 growth rate}

The broad measure of money supply (M2) reflects the degree of easing in credit markets. Tan et al. [1] found that M2 year-on-year growth had a negative impact on the leverage ratio of state-owned enterprises before the financial crisis, while after the financial crisis, the impact turned positive. Su and Zeng [3] measured credit default risk by taking the natural logarithm of banks' non-performing loans and eliminating the time trend, and the empirical results showed that the credit default risk was negatively correlated with the company's leverage ratio. Through the 
simulation of China's quarterly macroeconomic model, Li et al. [15] found that reducing the M2 growth rate under the soft budget constraint of state-owned enterprises could not achieve the policy goal of "deleveraging".

\subsection{Innovation}

Above all, this study focuses on the indirect influence of macro factors on the leverage ratio. First, it analyses the direct influence of macro factors on the leverage ratio and their indirect influence through micro enterprise-level variables. Second, the study adopts a different research perspective. While most previous studies focus on the leverage ratio of enterprises in a certain country or industry, this paper analyses the leverage ratio of enterprises in the Guangdong-Hong Kong-Macao Greater Bay Area. Finally, the research content of this paper is closely related to the national policies of deleveraging and planning in the Guangdong-Hong KongMacao Greater Bay Area, and the research results are of practical significance.

\section{Characteristics of the leverage ratio of non-financial enterprises in the Guangdong-Hong Kong-Macao Greater Bay Area}

This paper selects non-financial listed companies in Guangdong, Hong Kong and Macao for analysis. After data processing, the leverage ratio of non-financial enterprises in the greater bay area is shown to have been relatively stable over the past 19 years, with an average leverage ratio between $41.56 \%$ and $54.22 \%$. The peak of the average corporate leverage ratio was $54.22 \%$ in 2006 , the eve of the financial crisis. The leverage ratio of non-financial enterprises in the Guangdong-Hong Kong-Macao Greater Bay Area shows the following characteristics:

From the perspective of ownership (see Figure 1), before 2009, there was little difference in the leverage ratio of state-owned enterprises and non-state-owned enterprises in Guangdong, Hong Kong and Macao. The leverage ratio of stateowned enterprises began to be significantly higher than that of non-state-owned enterprises after 2009. From 2000 to 2006, the leverage ratio of both types of enterprises in the Guangdong-Hong Kong-Macao Greater Bay Area showed a steady rise, while it fell by nearly $12 \%$ in 2007 and further plunged from 2009 to 2011. However, the leverage ratio of non-state-owned enterprises fell by $19.2 \%$, a much greater decline than the $5 \%$ decrease sustained by state-owned enterprises. This marked the beginning of the divergence between state-owned enterprises and non-state-owned enterprises in terms of the leverage ratio. Since 2009, the leverage ratio of state-owned enterprises in the greater bay area of Guangdong, Hong Kong and Macao has remained approximately 50\%, with a steady trend. After adjustment, the average leverage ratio of non-state-owned enterprises has been maintained at $40 \%$ in recent years, showing an overall downward trend. In 2018, the leverage ratio of non-state-owned enterprises decreased by $21.55 \%$ compared with that of 2009 . 


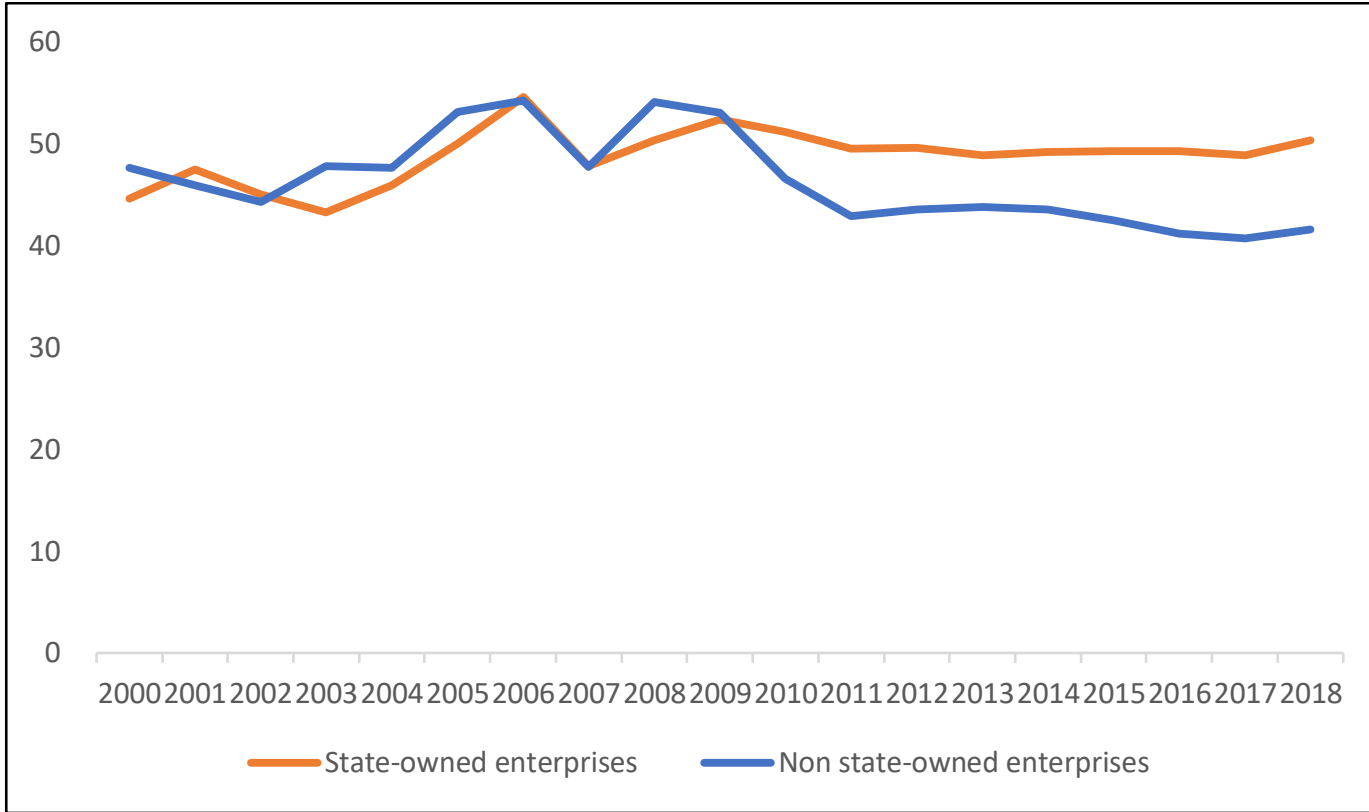

Data source: Wind

\section{Figure 1: Average leverage ratio of Guangdong-Hong Kong-Macao Greater Bay Area enterprises by ownership}

A more detailed classification of enterprises by ownership (see Figure 2) shows that since 2009, the average leverage ratio of state-owned enterprises in the central bay area of Guangdong, Hong Kong and Macao has been significantly higher than that of enterprises with other ownership, while foreign enterprises have the lowest leverage ratio. The average leverage ratio of central state-owned enterprises increased by $32.03 \%$ from 2007 to 2009 and then showed a steady downward trend. The average leverage ratio of central state-owned enterprises was $14.36 \%$ lower in 2018 than in 2009. The average leverage ratio of local state-owned enterprises peaked at $49.93 \%$ in 2007 and fell to $46.82 \%$ in 2008. In recent years, the leverage ratio of local state-owned enterprises has been stable, slightly increasing in 2018 . The average leverage ratio of foreign-funded enterprises has been relatively stable, fluctuating in the range of $38.52 \%$ to $47.39 \%$. 


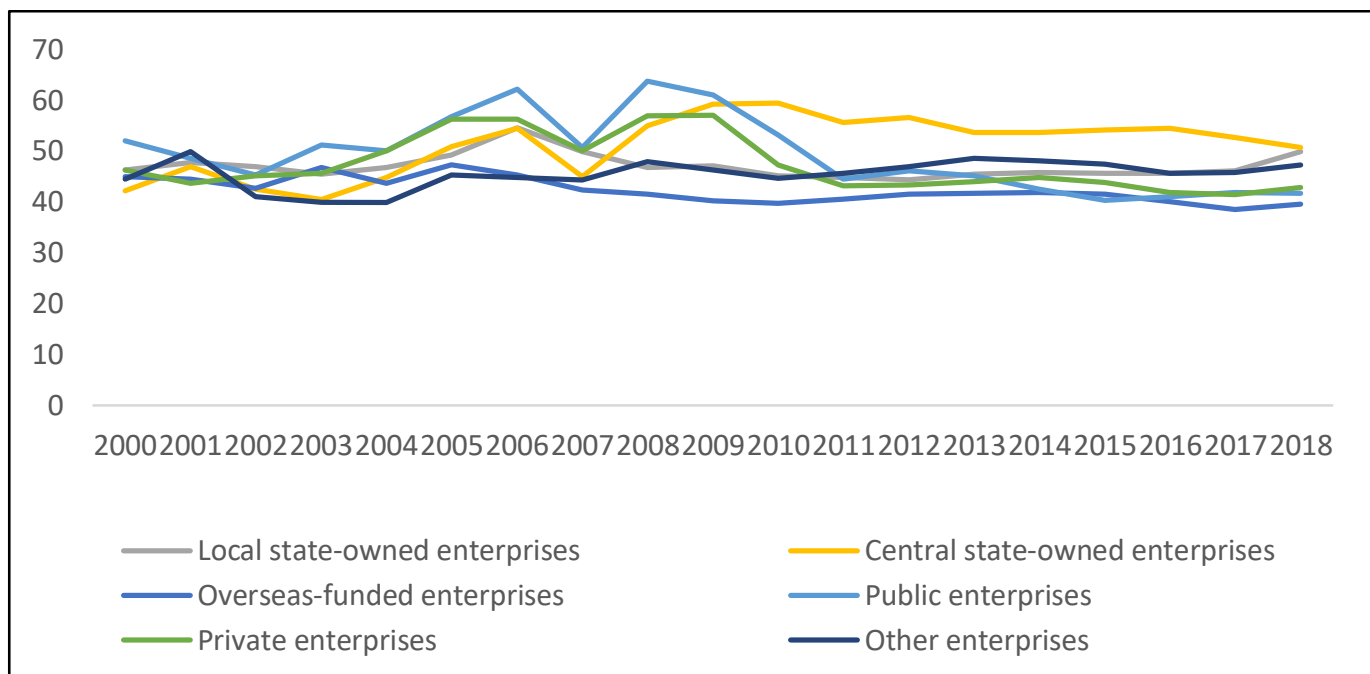

Data source: Wind

Figure 2: Average leverage ratio of Guangdong-Hong Kong-Macao Greater Bay Area enterprises: detailed division by ownership structure

Quantile analysis of the leverage ratio of central state-owned enterprises and local state-owned enterprises (see Figure 3) shows that after 2007, the leverage ratios of central state-owned enterprises in the lowest quantile (25\%), median and top quantile (75\%) became significantly higher than the leverage ratios of local stateowned enterprises in the corresponding quantiles. The leverage ratios of central state-owned enterprises in the $75 \%$ quantile have experienced an upward trend since 2007, indicating that the increasing leverage ratio of central state-owned enterprises is mainly driven by enterprises with high leverage ratio. Therefore, deleveraging efforts should focus on central state-owned enterprises with high leverage ratios.

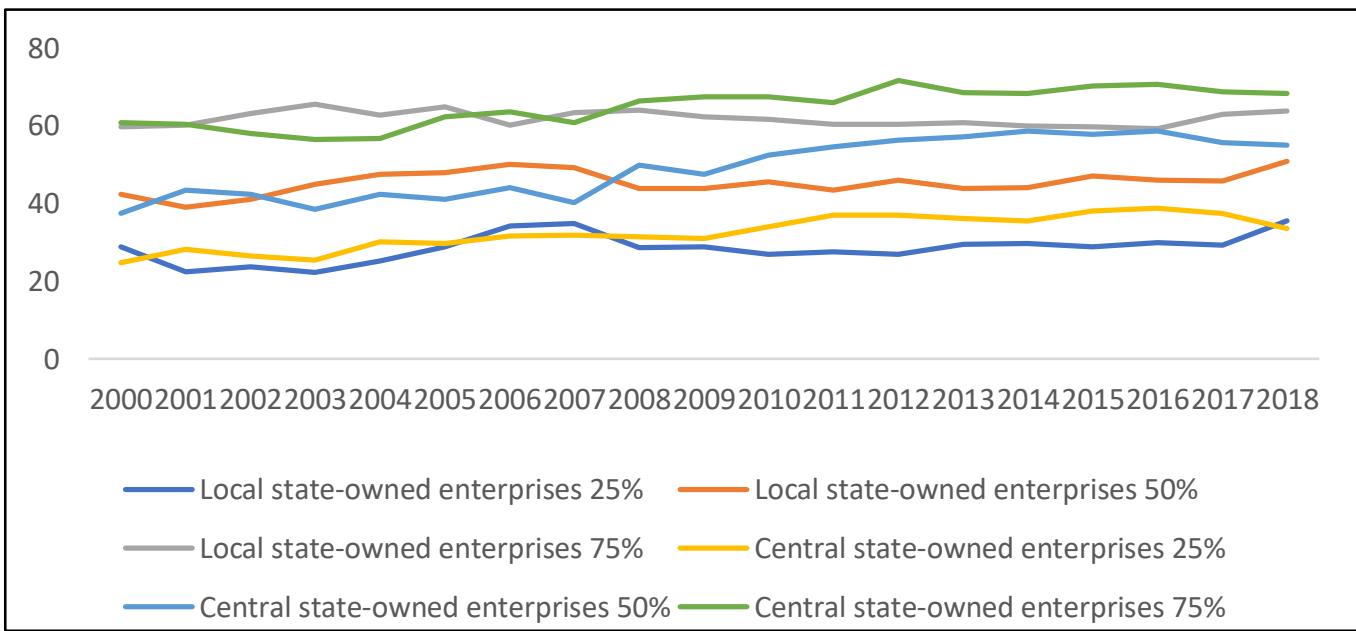

Data source: Wind

Figure 3: Average leverage ratio of enterprises in the Guangdong-Hong Kong-Macao Greater Bay Area: ownership quantile 
In terms of industry, the real estate management and development industry in the Guangdong-Hong Kong-Macao Greater Bay Area has the largest number of enterprises, accounting for $10.3 \%$ of non-financial enterprises. Other sectors, such as electronics, instruments and components, construction and engineering, textiles, clothing and luxury goods, hotels, restaurants and leisure industry, accounted for more than 5\%. The specific distribution of the top ten industries in the GuangdongHong Kong-Macao Greater Bay Area is shown in Figure 4.

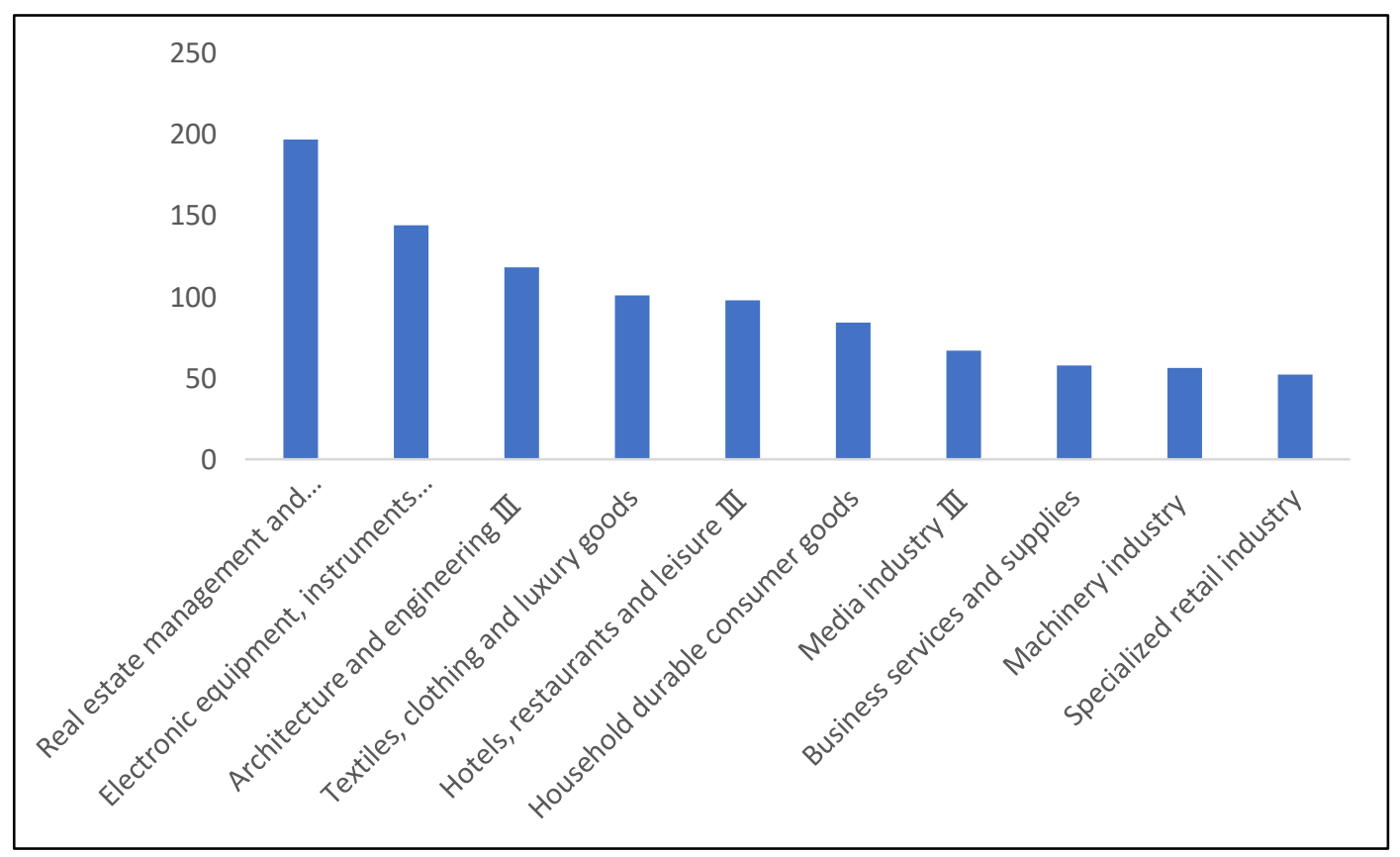

Data source: Wind

\section{Figure 4: Major industries of the Guangdong-Hong Kong-Macao Greater Bay Area in 2017}

Further analysis of the leverage ratio of major industries in the greater bay area (see Figure 5) shows that the construction and engineering industry has the highest average leverage ratio, with $57.56 \%$, and the textile, clothing and luxury industry has the lowest average leverage ratio, with $39.79 \%$. The leverage ratio of the construction and engineering industry increased significantly from 2010 to 2013 , rising by $18.79 \%$, and then steadily declined, falling by $21.52 \%$ in 2018 compared with 2013. In recent years, the growth of the leverage ratio has become obvious mainly among enterprises in the real estate management and development industry, among which the average asset-liability ratio reached a peak of $49.24 \%$ in 2006 . After a period of fluctuations, the ratio began to rise steadily in 2013, presenting an increase of $9.56 \%$ in 2018 compared with 2013. Overall, the average leverage ratio differs significantly across industries. 


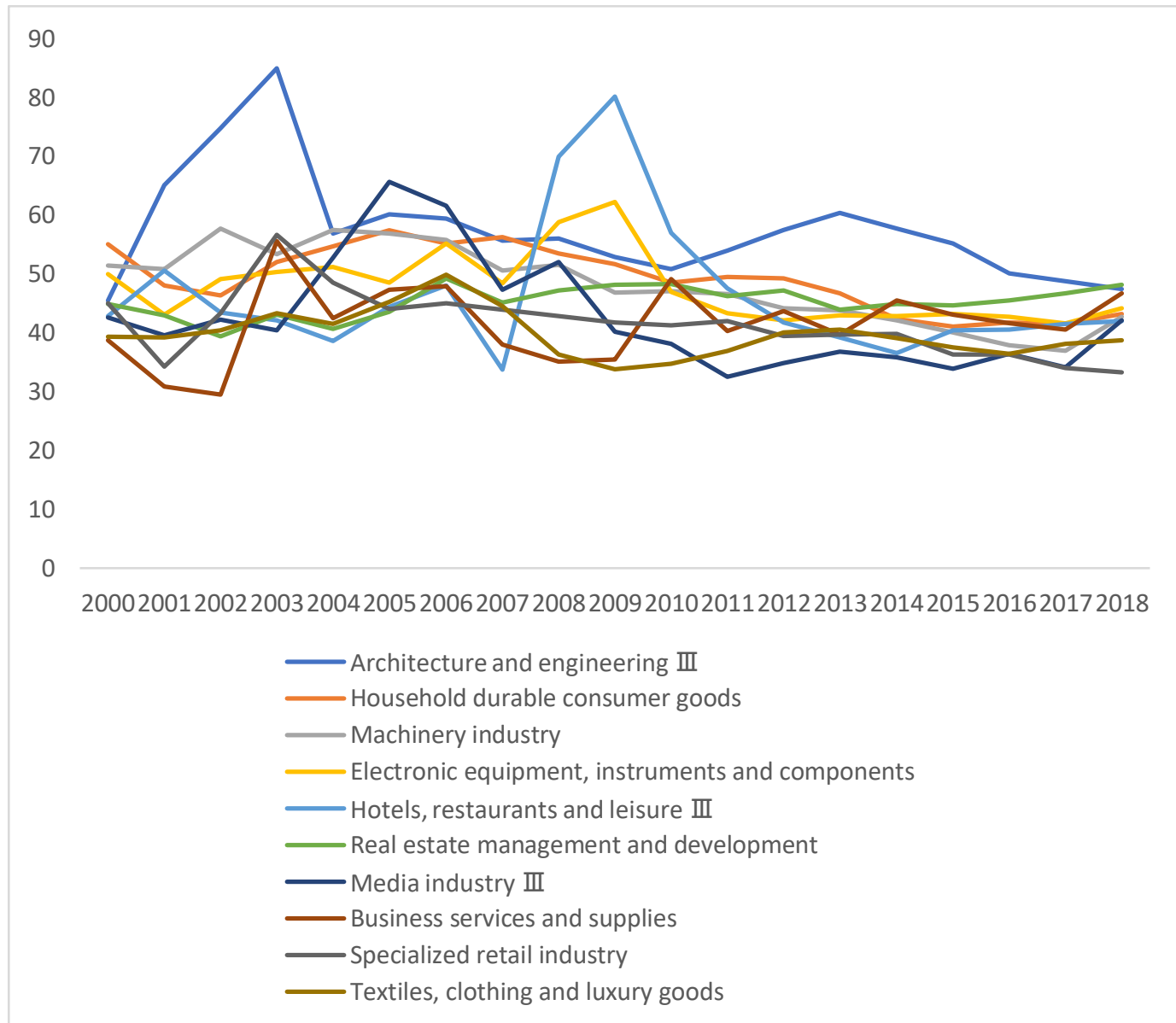

Data source: Wind

\section{Figure 5: Average leverage ratio of enterprises in the Guangdong-Hong Kong-Macao Greater Bay Area: major industries}

From the regional perspective, on the whole, non-financial enterprises in Macao have the lowest leverage ratio in the greater bay area, and these are mainly foreignfunded and private enterprises, without state-owned enterprises. Before 2008, enterprises in Guangdong had a significantly higher leverage ratio than enterprises in Hong Kong and Macao. Since 2014, the leverage ratio of enterprises in Guangdong, Hong Kong and Macao has been trending in the same direction. In the last three years, the leverage ratio of enterprises in Guangdong Province has grown at the highest rate, with 5.12\%, while that of enterprises in Macao has grown most slowly, decreasing by $10.22 \%$. The leverage ratio of non-financial companies in Hong Kong is less volatile, falling 2.66 percentage points, on average, in the past three years. The average leverage ratio of enterprises in the Guangdong-Hong Kong-Macao Greater Bay Area is shown in Figure 6. 


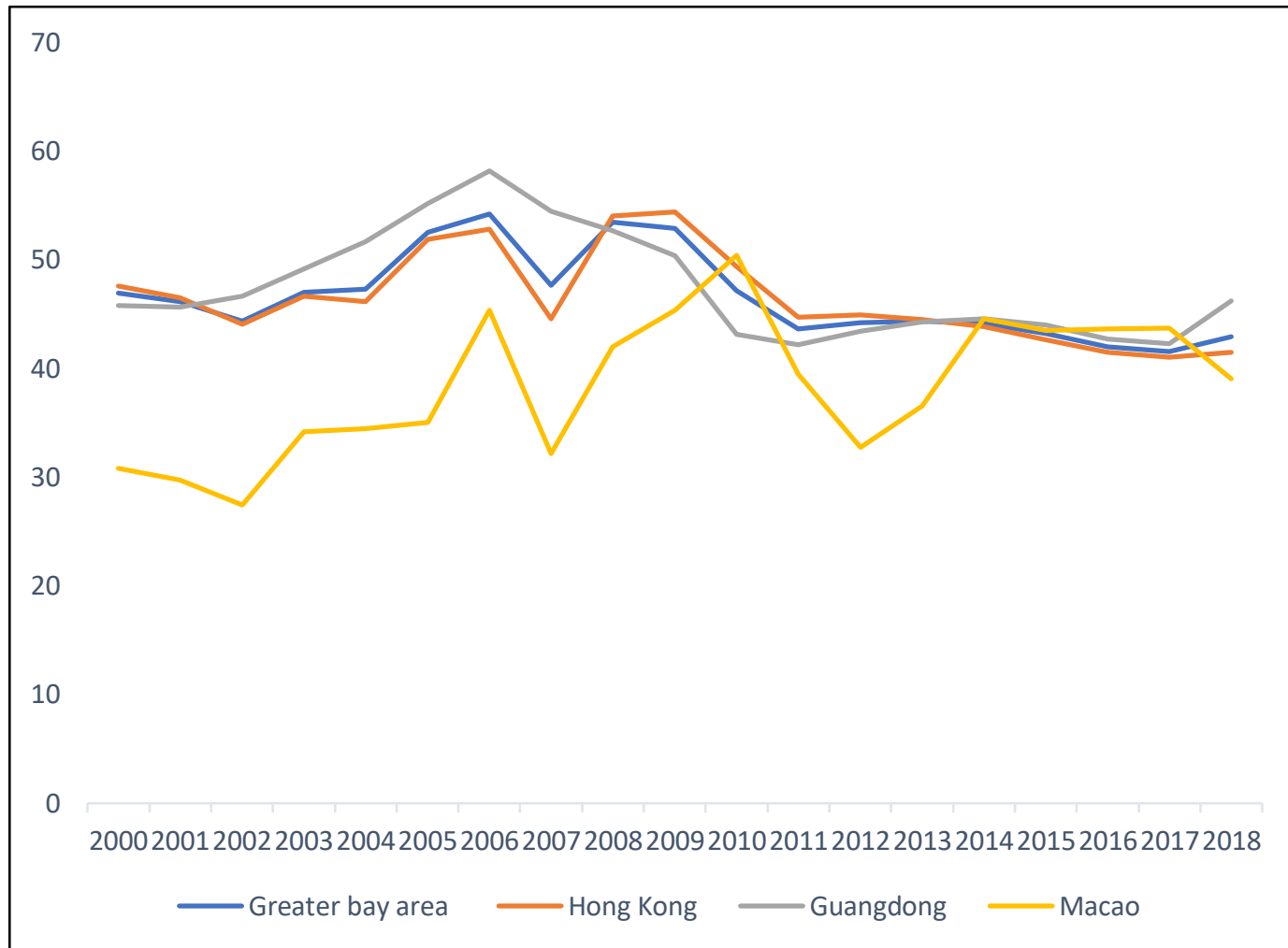

Data source: Wind

\section{Figure 6: Average leverage ratio of enterprises in the Guangdong-Hong Kong-Macao Greater Bay Area}

Figure 7 compares the leverage ratio of non-financial enterprises in the GuangdongHong Kong-Macao Greater Bay Area with that of non-financial enterprises in other parts of China. The leverage ratio of enterprises in Guangdong, Hong Kong, Macao and the mainland increased until 2006; in that year, the leverage ratio of nonfinancial enterprises on the mainland began to present an overall downward trend, decreasing by 26.06 percentage points in 2018 compared with 2006 . Concerning the non-financial enterprises in Guangdong, Hong Kong and Macao, after a short decline in 2007, the leverage ratio increased until 2009, and it again decreased until 2018, presenting a ratio $18.87 \%$ lower than the level in 2009. Since 2015, the average leverage ratio of non-financial enterprises in Guangdong, Hong Kong and Macao has been slightly higher than that of non-financial enterprises in other parts of China.

In the past three years, the non-financial enterprises in Guangdong, Hong Kong and Macao have experienced a smaller average decrease in the leverage ratio than similar enterprises in other regions in China. The leverage ratio of non-financial enterprises in the greater bay area has decreased by 0.67 percentage points, while the average leverage ratio of non-financial enterprises in other regions of China has decreased significantly, falling $3.47 \%$ year-on-year. 


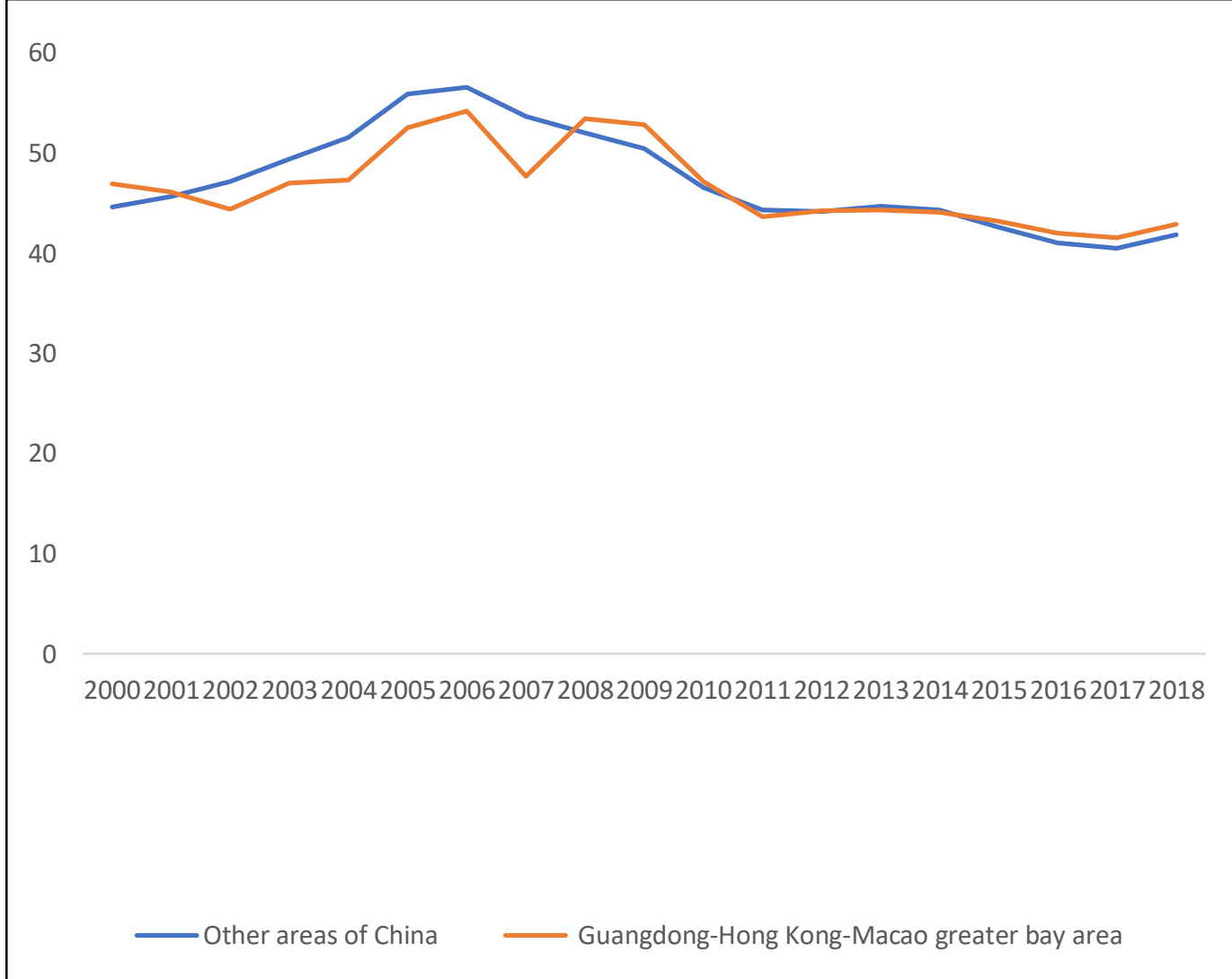

Data source: Wind

Figure 7: Comparison of the average leverage ratio of non-financial enterprises in Guangdong-Hong Kong-Macao Greater Bay Area and other regions in China

A comparison of the leverage ratio of non-financial enterprises in the GuangdongHong Kong-Macao Greater Bay Area with that of major economies in the world shows that the leverage ratio of non-financial enterprises in the greater bay area is the lowest. Overall, the average leverage ratio of non-financial companies in France is the highest, and it has been declining since 2013. The leverage ratio of nonfinancial enterprises in Germany shows a trend of moderate growth on the whole; this growth is inseparable from the country's developed banking system, which makes it easier for enterprises to borrow money from banks and thus increases their leverage ratio. The leverage ratio of non-financial enterprises in the United States is highly volatile, reaching a peak of 59.05\% in 2012. Japan's non-financial corporate leverage is the smoothest. The leverage ratio of non-financial enterprises in the UK has shown a relatively obvious trend of decline since 2014, with a slight rise in 2018. The leverage ratio of non-financial enterprises in the Guangdong-Hong Kong-Macau Greater Bay Area and major economies in the world is shown in Figure 8. 


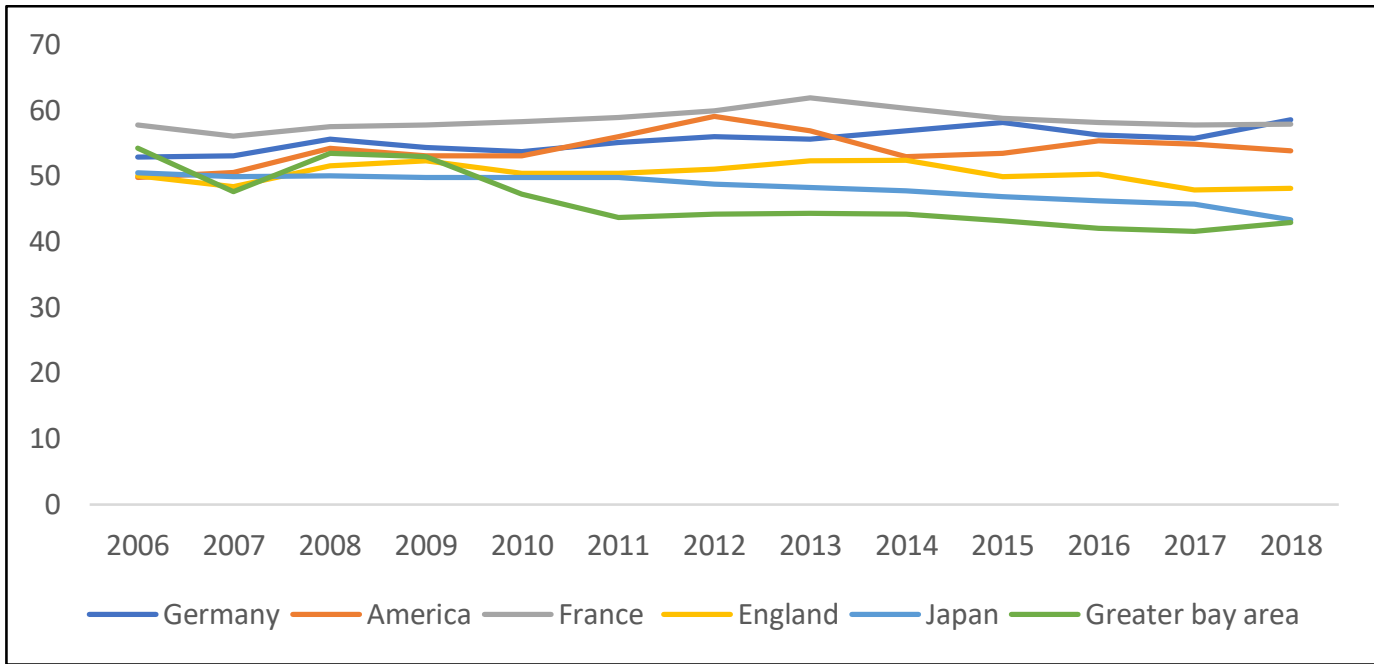

Data source: Wind

Figure 8: Leverage ratio of non-financial enterprises in the Guangdong-Hong Kong-Macau Greater Bay Area and major economies in the world

Before 2009, the leverage volatility of non-financial enterprises in the GuangdongHong Kong-Macao Greater Bay Area showed a trend similar to the trends in Germany, the United States and Britain. However, since 2009, the trend of leverage volatility in the Guangdong-Hong Kong-Macao Greater Bay Area has started to deviate, showing a significant decline. In 2018, the leverage ratio of non-financial enterprises in China's Guangdong-Hong Kong-Macao Greater Bay Area dropped by $18.87 \%$ compared with 2009 . Compared with the leverage ratio of non-financial enterprises in other major economies in the world, China's non-financial enterprises in Guangdong, Hong Kong and Macao have the lowest leverage ratio.

\section{Research design}

\subsection{Data}

To ensure the comparability of data considering the differences in financial data disclosure between mainland China and Hong Kong and Macao before 2006, this paper selects the data of A-share and Hong Kong stock market listed companies in Guangdong, Hong Kong and Macao from 2007 to 2017, excluding the following samples: (1) listed financial companies (insurance, commercial banks, capital markets, etc.), (2) ST and *ST enterprises, (3) companies with missing data on indicators such as leverage ratio, (4) enterprises belonging to the comprehensive industry category, (5) industry samples with fewer than 5 enterprises in the industry and (6) duplicate company samples.

A total of 890 listed companies were screened using the above criteria. The data in this paper (including macro data and micro data at the company level) are all from the Wind database. The tool for data processing used in this paper is Stata14. To 
eliminate the influence of extreme values on the research results, this paper winsorizes the extreme values of the micro-level data by reducing the tails of the data at the lowest and highest $1 \%$ of the index.

The main variable definitions in this paper are shown in Table 1.

Table 1: Selection of dependent variables and independent variables

\begin{tabular}{|c|c|c|c|}
\hline $\begin{array}{c}\text { Variable } \\
\text { type }\end{array}$ & Variable name & $\begin{array}{l}\text { Variable } \\
\text { symbol }\end{array}$ & Note \\
\hline $\begin{array}{c}\text { Dependent } \\
\text { variable }\end{array}$ & Leverage ratio & Liaratio & Total liabilities/total assets \\
\hline \multirow{13}{*}{$\begin{array}{l}\text { Independent } \\
\text { variable }\end{array}$} & Return on assets & ROA & Net profit/total assets \\
\hline & Tangible asset ratio & Tangibility & Tangible assets/total assets \\
\hline & Asset turnover & AT & Revenue/total assets \\
\hline & Liquidity ratio & Liquidity & Current assets/current liabilities \\
\hline & Company scale & Size & Logarithm of total assets \\
\hline & Growth ability & Grow & Gross revenue growth rate \\
\hline & Non-debt tax shield & Tax & $\begin{array}{c}\text { Depreciation and } \\
\text { amortization/total assets }\end{array}$ \\
\hline & Company property & Property & $\begin{array}{l}\text { State-owned and non-state-owned } \\
\text { enterprises }\end{array}$ \\
\hline & Industry & Industry & Median industry leverage \\
\hline & GDP growth rate & GDP & Year-on-year growth rate of GDP \\
\hline & Inflation rate & CPI & Year-on-year growth of CPI \\
\hline & M2 growth rate & M2 & Year-on-year growth of M2 \\
\hline & EPU & Pindex & Economic policy uncertainty index \\
\hline
\end{tabular}

\subsection{Empirical model}

In this paper, a fixed effect model is selected after the Hausman test of sample data. Then, the joint significance test of annual dummy variables was carried out, and the test results were significant. Finally, the time fixed effect model (two-way fixed effect model) was selected.

$$
\begin{aligned}
& \text { liaratio }_{i, t}=\alpha_{i, t}+\beta_{i, t} * \text { micro }_{i, t}+\gamma_{i, t} * \text { macro }_{t}+\delta_{i, t} \\
& \beta_{i, t}=\beta_{i, 0}+\beta_{2} * \text { macro }_{t}
\end{aligned}
$$




\section{Empirical results and analysis}

\subsection{Empirical test results of influencing factors at the company level}

The regression results of micro variables are shown in Table 2.

Table 2: Regression results of micro variables

\begin{tabular}{|c|c|c|c|c|c|}
\hline & Total sample & $\begin{array}{c}\text { State-owned } \\
\text { enterprises }\end{array}$ & $\begin{array}{c}\text { Non-state-owned } \\
\text { enterprises }\end{array}$ & $\begin{array}{c}\text { Enterprise } \\
\text { S with } \\
\text { HLR\# } \\
\end{array}$ & $\begin{array}{l}\text { Enterprises } \\
\text { with LLR\#\# }\end{array}$ \\
\hline \multirow{2}{*}{ ROA } & $-0.571 * * *$ & $-0.432 * * *$ & $-0.579 * * *$ & $-0.618 * * *$ & $-0.0175^{* *}$ \\
\hline & $(-0.0946)$ & $(-0.0642)$ & $(-0.101)$ & $(-0.165)$ & $(-0.0076)$ \\
\hline \multirow{2}{*}{ Size } & $-5.514 * *$ & -1.536 & $-6.209 * *$ & $-15.53^{* * *}$ & 0.073 \\
\hline & $(-2.217)$ & $(-1.714)$ & $(-2.485)$ & $(-4.109)$ & $(-0.345)$ \\
\hline \multirow{2}{*}{ Tangibility } & $-0.219 * * *$ & $-0.388 * * *$ & $-0.204 * * *$ & -0.136 & -0.022 \\
\hline & $(-0.0639)$ & $(-0.124)$ & $(-0.07)$ & $(-0.239)$ & $(-0.0141)$ \\
\hline \multirow{2}{*}{ AT } & $5.555^{*}$ & 1.876 & 5.833 & -7.782 & $2.271 * * *$ \\
\hline & $(-3.295)$ & $(-2.37)$ & $(-3.747)$ & $(-6.664)$ & $(-0.516)$ \\
\hline \multirow{2}{*}{ Liquidity } & $-1.342 * * *$ & $-1.454 * * *$ & $-1.346^{* * *}$ & -3.247 & $-0.389 * * *$ \\
\hline & $(-0.133)$ & $(-0.471)$ & $(-0.139)$ & $(-5.635)$ & $(-0.0208)$ \\
\hline \multirow{2}{*}{ Grow } & $0.00516^{*}$ & $0.0130 *$ & 0.00491 & 0.0000919 & 0.000144 \\
\hline & $(-0.00296)$ & $(-0.0075)$ & $(-0.00322)$ & $(-0.00562)$ & $(-0.00072)$ \\
\hline \multirow{2}{*}{$\operatorname{Tax}$} & $2.123^{* * *} *$ & 1.133 & $2.243 * * *$ & $3.174 * *$ & -0.0715 \\
\hline & $(-0.615)$ & $(-1.311)$ & $(-0.662)$ & $(-1.554)$ & $(-0.093)$ \\
\hline \multirow{2}{*}{ Industry } & $0.510^{* * * *}$ & $0.297 * *$ & $0.518 * * *$ & 0.283 & 0.0345 \\
\hline & $(-0.103)$ & $(-0.123)$ & $(-0.119)$ & $(-0.259)$ & $(-0.0249)$ \\
\hline \multirow{2}{*}{ Constant } & $155.3 * * *$ & $92.92 * *$ & $167.8 * * *$ & $413.8 * * *$ & $15.20 * *$ \\
\hline & $(-49.09)$ & $(-39.33)$ & $(-54.68)$ & $(-92.88)$ & $(-7.623)$ \\
\hline R-sq & 0.1924 & 0.3138 & 0.1943 & 0.232 & 0.3189 \\
\hline $\begin{array}{c}\text { Company } \\
\text { number }\end{array}$ & 890 & 132 & 758 & 475 & 480 \\
\hline
\end{tabular}

Note: \# high leverage ratio \#\# low leverage ratio

The standard deviations of the sample statistics are shown in parentheses. *p $<0.1, * * p<0.05$, $* * * \mathrm{p}<0.01$. Enterprises with high leverage ratios are those in the bottom $25 \%$, while enterprises with low leverage ratios are those in the top $25 \%$. 


\subsubsection{Profitability}

Enterprise profitability has a significant negative correlation with the leverage ratio of each group. The more profitable a company is, the more internal retained earnings it has and the less dependent it is on debt financing, leading to a lower leverage ratio. Therefore, the conclusion of this study is consistent with the pecking order theory. However, the static tradeoff theory holds that profitability has a positive impact on an enterprise's leverage ratio. The above results show that profitability has a more significant negative impact on the asset-liability ratio of enterprises with a high leverage ratio than with a low leverage ratio. Enterprises with high leverage ratios face great default risk. When their profitability is enhanced, they will choose to use internal retained earnings or equity financing to reduce their debt ratio.

\subsubsection{Enterprise scale}

There is a significant negative correlation between enterprise scale and assetliability ratio. Larger enterprises with greater transparency of information and a lower degree of information asymmetry face a lower cost of equity financing. The results of this paper are consistent with the conclusion of the pecking order theory. Enterprise size has a significant negative impact on the asset-liability ratio of nonstate-owned enterprises, high-leverage enterprises and all sample enterprises, while the negative impact on state-owned enterprises is not significant.

\subsubsection{Tangible assets}

The ratio of tangible assets has a significant negative impact on the leverage ratio of state-owned enterprises, non-state-owned enterprises and all sample enterprises. It has a more obvious negative impact on the leverage ratio of state-owned enterprises than non-state-owned enterprises. Typically, the more tangible assets a company has, the more assets it can use as collateral, and the more debt it can finance. However, in China, state-owned enterprises are implicitly guaranteed by the government and have close relationships with banks, which greatly reduces the cost to banks of evaluating their qualifications. The debt financing available to stateowned enterprises does not depend on their own tangible assets. Moreover, according to the pecking order theory, enterprises with high tangible assets have lower information asymmetry and prefer equity financing, which is similar to the research results of Tan et al. [1].

\subsubsection{Asset turnover ratio}

At the significance level of $10 \%$, the asset turnover rate is positively correlated for the overall sample of enterprises and has a significant positive impact on the lowleverage enterprises. The higher the asset turnover rate is, the better the operating capacity of the enterprise, making it easier to obtain loans. 


\subsubsection{Liquidity}

The liquidity ratio has a significant negative impact on the leverage ratio. The higher the liquidity ratio is, the stronger the short-term solvency of the enterprise is, and the easier it is to obtain loans. However, a firm with a high liquidity ratio may borrow against its current assets.

The research results of this paper show that the liquidity ratio has a significant negative impact on the asset-liability ratio of the overall sample, state-owned enterprises, non-state-owned enterprises and low-leverage enterprises, while the leverage ratio of high-leverage enterprises is not significant. The main reason is that the high default risk faced by enterprises with high leverage ratio and their high short-term solvency are hedged, which weakens the negative impact of the liquidity ratio.

\subsubsection{Growth ability}

The influence of growth capacity on the leverage ratio is not significant; the positive impact on state-owned enterprises and the overall sample is significant only at the $10 \%$ level. Strong growth ability means that enterprises have better development prospects but also increased risks. In this situation, the impact on the leverage ratio is not significant.

\subsubsection{Non-debt tax shield}

The non-debt tax shield of the overall sample, non-state-owned enterprises and high-leverage enterprises has a significant positive correlation with the leverage ratio. Generally, the higher the ratio of depreciation and amortization to the total assets is, the less income the enterprise can obtain through interest tax deduction, and the lower the asset-liability ratio of the company. However, currently, depreciation data include the depreciation of not only fixed assets but also oil and gas assets and productive biological assets, and the depreciation is related to other explanatory variables, which will have an impact on the leverage ratio. These reasons may explain the above conclusion, which is similar to the findings of Tan et al. [1] and Xiao [16].

\subsubsection{Industry}

The median leverage ratio of the industry has a significant positive impact on the leverage ratio. The median leverage ratio of the industry can reflect the operating characteristics and capital structure of an industry, which is an important factor affecting the leverage ratio.

\subsection{Empirical test results of influencing factors at the macro level}

The single regression results of the macro variables are shown in Table 3. 
Table 3: Single regression results of macro variables

\begin{tabular}{|c|c|c|c|c|c|}
\hline & Total sample & $\begin{array}{c}\text { State-owned } \\
\text { enterprises }\end{array}$ & $\begin{array}{c}\text { Non-state-owned } \\
\text { enterprises }\end{array}$ & $\begin{array}{c}\text { Enterprises } \\
\text { with HLR \# }\end{array}$ & $\begin{array}{c}\text { Enterprises } \\
\text { with LLR \#\# }\end{array}$ \\
\hline \multirow{2}{*}{ GDP } & $0.414^{* *}$ & 1.113 & $0.490^{* *}$ & -0.133 & 0.0611 \\
\cline { 2 - 6 } & $(-0.199)$ & $(-0.683)$ & $(-0.217)$ & $(-0.946)$ & $(-0.0882)$ \\
\hline \multirow{2}{*}{ Pindex } & -0.00858 & $0.0313^{*}$ & -0.0107 & $-0.0629^{* *}$ & $-0.00518^{*}$ \\
\cline { 2 - 6 } & $(-0.00761)$ & $(-0.0161)$ & $(-0.00881)$ & $(-0.0307)$ & $(-0.00311)$ \\
\hline \multirow{2}{*}{ CPI } & 0.115 & 0.527 & 0.305 & -0.641 & $-0.491^{* *}$ \\
\cline { 2 - 6 } & $(-0.388)$ & $(-0.716)$ & $(-0.468)$ & $(-1.314)$ & $(-0.221)$ \\
\hline \multirow{2}{*}{ M2 } & $-0.272 *$ & -0.141 & -0.279 & $-0.836 *$ & $-0.0894^{* *}$ \\
\cline { 2 - 7 } & $(-0.158)$ & $(-0.234)$ & $(-0.205)$ & $(-0.477)$ & $(-0.0402)$ \\
\hline \multirow{2}{*}{ Constant } & $46.44 * * *$ & $31.36^{* * *}$ & $45.69 * * *$ & $110.4 * * *$ & $16.62 * * *$ \\
\cline { 2 - 7 } & $(-4.989)$ & $(-9.244)$ & $(-6.061)$ & $(-19.37)$ & $(-1.475)$ \\
\hline \multirow{2}{*}{ R-sq } & 0.0062 & 0.0166 & 0.0086 & 0.0391 & 0.0127 \\
\hline \multirow{2}{*}{ Company number } & 890 & 132 & 758 & 475 & 480 \\
\hline
\end{tabular}

Note: \# high leverage ratio \#\# low leverage ratio

The standard deviations of the sample statistics are shown in parentheses. ${ }^{*} \mathrm{p}<0.1, * * \mathrm{p}<0.05$, $* * * \mathrm{p}<0.01$. Enterprises with high leverage ratios are those in the bottom $25 \%$, while enterprises with low leverage ratios are those in the top $25 \%$. 


\subsubsection{Direct influence}

The economic growth rate has a significant positive impact on the leverage ratio of non-state-owned enterprises and all sample enterprises. In general, when the economy is growing, it is easier for companies to borrow, so their leverage is higher. According to the tradeoff theory, in such times, enterprise profit increases, risk decreases, and enterprises prefer to increase leverage to obtain income. In times of economic recession, enterprise operation is more difficult, and the risks of default and bankruptcy are greater, so enterprises choose to reduce the asset-liability ratio. According to the theory of balance sheet recession, when an economic downturn leads to the deterioration of corporate balance sheets and insolvency, the primary goal of enterprises is no longer to maximize profits but to reduce liabilities to maintain the goodwill of the public and the status of the enterprise.

The index of policy uncertainty has a significant negative impact on enterprises with high leverage ratios. The economic policy uncertainty index is mainly used to reflect the economic and policy uncertainty of an economy. When policy uncertainty rises, non-state-owned enterprises will generally delay investment, and high-leverage enterprises will be more cautious toward investment to avoid risks brought by policy uncertainty, so the asset-liability ratio of high-leverage enterprises will decline. However, policy uncertainty has little impact on state-owned enterprises. According to $\mathrm{Lu}$ et al. [6], state-owned enterprises are less likely than non-state-owned enterprises to have excessive debt, that is, to deviate from the target debt ratio. Therefore, banks are more willing to lend to state-owned enterprises when policy uncertainty rises.

Inflation has a significant negative impact on the debt ratio of only low-leverage non-financial enterprises in Guangdong, Hong Kong and Macao. Inflation increases the total asset scale of enterprises. A larger total asset scale entails lower equity financing cost, less debt, and a lower leverage ratio.

M2 growth is negatively correlated with the leverage ratio of non-financial enterprises in the greater bay area. The M2 growth rate reflects the degree of credit market easing, which enhances enterprises' access to debt financing. After the financial crisis, although stimulus policies amounting to 4 trillion yuan were adopted, enterprises reduced their leverage ratio to avoid risks. The direct effects of the micro and macro variables on the leverage ratio are shown in Table 4. 
Table 4: Direct effects of micro and macro variables on the leverage ratio

\begin{tabular}{|c|c|c|c|c|c|}
\hline & $\begin{array}{c}\text { Total } \\
\text { sample }\end{array}$ & $\begin{array}{c}\text { State-owned } \\
\text { enterprises }\end{array}$ & $\begin{array}{c}\begin{array}{c}\text { Non-state-owned } \\
\text { enterprises }\end{array} \\
\end{array}$ & $\begin{array}{l}\text { Enterprises } \\
\text { with HLR \# }\end{array}$ & $\begin{array}{c}\text { Enterprises } \\
\text { with LLR \#\# }\end{array}$ \\
\hline \multirow{2}{*}{ ROA } & $-0.572 * * *$ & $-0.438 * * *$ & $-0.582 * * *$ & $-0.604 * * *$ & $-0.0172 * *$ \\
\hline & $(-0.0942)$ & $(-0.0649)$ & $(-0.1)$ & $(-0.165)$ & $(-0.00759)$ \\
\hline \multirow{2}{*}{ Size } & $-5.466 * *$ & -1.447 & $-6.107 * *$ & $-15.81 * * *$ & 0.0715 \\
\hline & $(-2.249)$ & $(-1.653)$ & $(-2.523)$ & $(-4.225)$ & $(-0.347)$ \\
\hline \multirow{2}{*}{ Tangibility } & $-0.219 * * *$ & $-0.393 * * *$ & $-0.204 * * *$ & -0.129 & -0.0217 \\
\hline & $(-0.0647)$ & $(-0.123)$ & $(-0.0712)$ & $(-0.24)$ & $(-0.0141)$ \\
\hline \multirow{2}{*}{ TA } & $5.559^{*}$ & 1.998 & 5.833 & -8.115 & $2.278 * * *$ \\
\hline & $(-3.291)$ & $(-2.362)$ & $(-3.744)$ & $(-6.604)$ & $(-0.516)$ \\
\hline \multirow{2}{*}{ Liquidity } & $-1.341 * * *$ & $-1.437 * * *$ & $-1.344 * * *$ & -3.421 & $-0.388 * * *$ \\
\hline & $(-0.133)$ & $(-0.454)$ & $(-0.14)$ & $(-5.585)$ & $(-0.0209)$ \\
\hline \multirow{2}{*}{ Grow } & $0.00516^{*}$ & $0.0133 *$ & 0.0049 & -0.000000247 & 0.000173 \\
\hline & $(-0.00296)$ & $(-0.00755)$ & $(-0.00322)$ & $(-0.00561)$ & $(-0.000727)$ \\
\hline \multirow{2}{*}{$\operatorname{Tax}$} & $2.129 * * *$ & 1.163 & $2.255 * * *$ & $3.124 * *$ & -0.0812 \\
\hline & $(-0.616)$ & $(-1.322)$ & $(-0.663)$ & $(-1.556)$ & $(-0.0934)$ \\
\hline \multirow{2}{*}{ Industry } & $0.509 * * *$ & $0.268 * *$ & $0.516^{* * * *}$ & 0.3 & 0.033 \\
\hline & $(-0.103)$ & $(-0.13)$ & $(-0.12)$ & $(-0.253)$ & $(-0.0248)$ \\
\hline \multirow{2}{*}{ GDP } & 0.137 & $1.100 *$ & 0.179 & -0.591 & 0.023 \\
\hline & $(-0.203)$ & $(-0.573)$ & $(-0.222)$ & $(-0.853)$ & $(-0.0745)$ \\
\hline \multirow{2}{*}{ Pindex } & 0.00918 & $0.0391 * *$ & 0.00958 & 0.0111 & -0.0034 \\
\hline & $(-0.00856)$ & $(-0.0192)$ & $(-0.00976)$ & $(-0.0269)$ & $(-0.00258)$ \\
\hline \multirow{2}{*}{ CPI } & 0.0019 & 0.606 & 0.2 & -1.142 & $-0.356 * *$ \\
\hline & $(-0.392)$ & $(-0.592)$ & $(-0.485)$ & $(-1.336)$ & $(-0.176)$ \\
\hline \multirow{2}{*}{ M2 } & 0.00969 & -0.00973 & 0.0578 & -0.528 & -0.0367 \\
\hline & $(-0.146)$ & $(-0.132)$ & $(-0.196)$ & $(-0.427)$ & $(-0.0369)$ \\
\hline \multirow{2}{*}{ Constant } & $152.1 * * *$ & $74.94 * *$ & $161.9 * * *$ & $436.8 * * *$ & $16.84 * *$ \\
\hline & $(-50.28)$ & $(-37.75)$ & $(-55.95)$ & $(-101.9)$ & $(-7.784)$ \\
\hline R-sq & 0.1925 & 0.3213 & 0.1945 & 0.2343 & 0.3212 \\
\hline $\begin{array}{c}\text { Company } \\
\text { number }\end{array}$ & 890 & 132 & 758 & 475 & 480 \\
\hline
\end{tabular}

Note: \# high leverage ratio \#\# low leverage ratio

The standard deviations of the sample statistics are shown in parentheses. ${ }^{*} \mathrm{p}<0.1, * * \mathrm{p}<0.05$, $* * * \mathrm{p}<0.01$. Enterprises with high leverage ratios are those in the bottom $25 \%$, while enterprises with low leverage ratios are those in the top $25 \%$.

Combining the explanatory variables at the micro enterprise level and macro level yields the regression results presented below. The results show that after the addition of micro-level explanatory variables, the significant effect of the macro- 
level explanatory variables on the leverage ratio decreases mainly because the latter variables can affect the enterprise-level variables.

\subsubsection{Indirect influence}

Macro variables can affect the corporate leverage ratio not only directly but also indirectly by influencing the explanatory variables at the micro level. The paper uses the interaction terms of the macro- and micro-level explanatory variables to express the indirect influence of the macro variables on the corporate leverage ratio. The signs after $\beta \mathrm{i}, \mathrm{t}$ represent the signs of the regression results of the micro-level explanatory variables, and an * indicates that the influence of an explanatory variable at the company level on the leverage ratio is significant or mostly significant. When the sign of the cross term is consistent with the sign of the result at the company level, it indicates that a positive change in the macro-level variable will lead to an increased effect of the micro-level variable; if the sign is inconsistent, it indicates that a positive change in the macro-level variable will weaken the influence of the micro-level explanatory variable. The indirect influence of the macro variables on the leverage ratio (state-owned enterprises) is shown in Table 5.

Table 5: Indirect influence of macro variables on the leverage ratio (state-owned enterprises)

\begin{tabular}{|c|c|c|c|c|}
\hline & GDP & Pindex & CPI & M2 \\
\hline ROA & 0.0175 & $-0.00282 * * *$ & 0.00396 & $0.0530 * * *$ \\
\hline$* \beta \mathrm{i}, \mathrm{t}:-$ & $(-0.0336)$ & $(-0.000852)$ & $(-0.0508)$ & $(-0.0103)$ \\
\hline Size & -0.202 & 0.00775 & -0.121 & -0.0968 \\
\hline$* \beta \mathrm{i}, \mathrm{t}:-$ & $(-0.137)$ & $(-0.00573)$ & $(-0.208)$ & $(-0.0675)$ \\
\hline Tangibility & $-0.0366^{* * *}$ & 0.000154 & -0.0102 & $-0.0119 * * *$ \\
\hline$* \beta \mathrm{i}, \mathrm{t}:-$ & $(-0.00824)$ & $(-0.000132)$ & $(-0.0081)$ & $(-0.00384)$ \\
\hline TA & -0.206 & -0.00482 & -0.435 & 0.0225 \\
\hline$\beta \mathrm{i}, \mathrm{t}:+$ & $(-0.191)$ & $(-0.00727)$ & $(-0.29)$ & $(-0.134)$ \\
\hline Liquidity & -0.0384 & 0.00484 & 0.194 & -0.0475 \\
\hline$* \beta \mathrm{i}, \mathrm{t}:-$ & $(-0.0868)$ & $(-0.00356)$ & $(-0.191)$ & $(-0.0589)$ \\
\hline Grow & $0.00336 *$ & -0.0001 & 0.000347 & -0.000869 \\
\hline$\beta \mathrm{i}, \mathrm{t}:+$ & $(-0.00175)$ & $(-0.000096)$ & $(-0.00388)$ & $(-0.00136)$ \\
\hline Tax & -0.0697 & -0.00147 & 0.0838 & -0.0609 \\
\hline$* \beta i, \mathrm{t}:+$ & $(-0.069)$ & $(-0.00309)$ & $(-0.0872)$ & $(-0.0572)$ \\
\hline Industry & -0.0236 & $0.00107 *$ & 0.0114 & $-0.0183 *$ \\
\hline$* \beta \mathrm{i}, \mathrm{t}:+$ & $(-0.0181)$ & $(-0.000609)$ & $(-0.0234)$ & $(-0.0109)$ \\
\hline R-sq & 0.3673 & 0.3642 & 0.3273 & 0.3668 \\
\hline Company number & 132 & 132 & 132 & 132 \\
\hline
\end{tabular}

Note: The standard deviations of the sample statistics are shown in parentheses. $* \mathrm{p}<0.1,{ }^{*} \mathrm{p}<<0.05, * * * \mathrm{p}<0.01$. 
For state-owned enterprises and non-state-owned enterprises in the greater bay area of Guangdong, Hong Kong and Macao, the increase in economic growth can strengthen the negative impact of the tangible asset ratio on the corporate leverage ratio. A higher tangible asset ratio means that enterprises face a lower degree of information asymmetry, and enterprises prefer equity financing. When the macro economy is growing, the stock market outlook is positive, which creates better equity financing conditions for enterprises with a high ratio of tangible assets. For non-state-owned enterprises in the greater bay area, the increase in economic growth also reduces the negative impact of the profitability and liquidity ratios on leverage.

Policy uncertainty strengthens the negative impact of profitability on the corporate leverage ratio. Enterprises with strong profitability generally have more retained earnings. When policy uncertainty increases, high-earning enterprises give priority to internal retained earnings to avoid the associated risks. For non-financial enterprises in the greater bay area, the increase in policy uncertainty weakens the negative impact of enterprise size on the leverage ratio. The larger an enterprise is, the lower its information asymmetry and equity financing cost. However, when policy uncertainty increases, the stock market risk increases, and the stock financing behavior of the enterprise decreases. Therefore, the increase in policy uncertainty weakens the negative impact of enterprise scale on the leverage ratio.

For non-state-owned enterprises in the greater bay area of Guangdong, Hong Kong and Macao, a rising inflation rate weakens the positive impact of asset turnover on the leverage ratio, but the positive impact of asset turnover on the leverage ratio is not significant. For state-owned enterprises, the indirect impact of the rising inflation rate on the leverage ratio is not significant.

The growth of M2 weakens the negative impact of profitability and strengthens the negative impact of the tangible asset ratio on the leverage ratio of non-financial enterprises in the Guangdong-Hong Kong-Macao Greater Bay Area. Enterprises with strong profitability prefer to use internal retained earnings, and the easy credit environment facilitates corporate borrowing, offsetting the negative impact of the preference for internal financing on the leverage ratio. Enterprises with a high ratio of tangible assets have lower information asymmetry and lower equity financing costs. The increase in the M2 growth rate creates a looser monetary environment for the stock market, and the tendency for equity financing increases, while the debt ratio decreases. The indirect influence of the macro variables on the leverage ratio (non-state-owned enterprises) is shown in Table 6. 
Table 6: Indirect influence of macro variables on the leverage ratio (non-state-owned enterprises)

\begin{tabular}{|c|c|c|c|c|}
\hline & GDP & Pindex & CPI & M2 \\
\hline ROA & $0.0421 * *$ & $0.00184 * * *$ & 0.0886 & $0.0322 * *$ \\
\hline$* \beta i, t:-$ & $(-0.0198)$ & $(-0.000609)$ & $(-0.0557)$ & $(-0.0143)$ \\
\hline Size & -0.0232 & $0.00666 * *$ & 0.13 & -0.196 \\
\hline$* \beta i, t:-$ & $(-0.149)$ & $(-0.00294)$ & $(-0.264)$ & $(-0.121)$ \\
\hline Tangibility & $-0.0488 * * *$ & 0.000119 & 0.0159 & $-0.0287 * * *$ \\
\hline$* \beta i, t:-$ & $(-0.00982)$ & $(-0.000196)$ & $(-0.0104)$ & $(-0.0101)$ \\
\hline TA & -0.656 & $-0.0304 * *$ & $-1.614 * *$ & -0.493 \\
\hline$\beta i, t:+$ & $(-0.475)$ & $(-0.0119)$ & $(-0.713)$ & $(-0.315)$ \\
\hline Liquidity & $0.0603 * *$ & -0.00115 & 0.0184 & 0.0179 \\
\hline$* \beta \mathrm{i}, \mathrm{t}:-$ & $(-0.0288)$ & $(-0.000749)$ & $(-0.0571)$ & $(-0.0182)$ \\
\hline Grow & 0.00000228 & 0.0000255 & 0.00139 & -0.0000901 \\
\hline$\beta \mathrm{i}, \mathrm{t}:+$ & $(-0.0009)$ & $(-0.0000259)$ & $(-0.00172)$ & $(-0.000625)$ \\
\hline Tax & 0.0691 & 0.00319 & 0.379 & -0.013 \\
\hline$* \beta \mathrm{i}, \mathrm{t}:+$ & $(-0.115)$ & $(-0.00225)$ & $(-0.231)$ & $(-0.0642)$ \\
\hline Industry & -0.0101 & 0.000597 & -0.00827 & 0.00831 \\
\hline$* \beta \mathrm{i}, \mathrm{t:}++$ & $(-0.0174)$ & $(-0.000415)$ & $(-0.0267)$ & $(-0.0123)$ \\
\hline R-sq & 0.2136 & 0.2088 & 0.2037 & 0.2089 \\
\hline Company number & 758 & 758 & 758 & 758 \\
\hline
\end{tabular}

Note: The standard deviations of the sample statistics are shown in parentheses. $* \mathrm{p}<0.1, * * \mathrm{p}<0.05, * * * \mathrm{p}<0.01$.

\subsubsection{Robustness test}

The endogeneity of this model mainly comes from the interaction and mutual influence between the leverage ratio of non-financial enterprises in the greater bay area and explanatory variables at the enterprise level. To eliminate the ability of the leverage ratio to explain the micro-level variables, this paper selects the lag period of the leverage ratio and the explanatory variables at the micro level of enterprises in the current period for regression. The regression results, shown in the following table, are basically consistent with the empirical test results above, supporting the robustness of the results. The regression results of the instrumental variables are shown in Table 7. 
Table 7: Regression results of instrumental variables

\begin{tabular}{|c|c|c|c|c|c|}
\hline & $\begin{array}{c}\text { Total } \\
\text { sample }\end{array}$ & $\begin{array}{c}\text { State-owned } \\
\text { enterprises }\end{array}$ & $\begin{array}{c}\text { Non-state-owned } \\
\text { enterprises }\end{array}$ & $\begin{array}{l}\text { Enterprises } \\
\text { with HLR \# }\end{array}$ & $\begin{array}{l}\text { Enterprises } \\
\text { with LLR \# }\end{array}$ \\
\hline \multirow{2}{*}{ ROA } & $-0.447 * * *$ & $-0.319 * * *$ & $-0.459 * * *$ & $-0.462 * *$ & -0.0133 \\
\hline & $(-0.0871)$ & $(-0.0833)$ & $(-0.0932)$ & $(-0.181)$ & $(-0.0101)$ \\
\hline \multirow{2}{*}{ Size } & 2.963 & -0.743 & 3.142 & 5.895 & $0.622 *$ \\
\hline & $(-2.086)$ & $(-1.538)$ & $(-2.375)$ & $(-3.721)$ & $(-0.343)$ \\
\hline \multirow{2}{*}{ Tangibility } & -0.0939 & $-0.348 * * *$ & -0.0682 & -0.00208 & -0.0196 \\
\hline & $(-0.0572)$ & $(-0.0602)$ & $(-0.063)$ & $(-0.179)$ & $(-0.0127)$ \\
\hline \multirow{2}{*}{ TA } & -0.249 & 0.32 & -0.236 & -8.98 & -0.471 \\
\hline & $(-4.052)$ & $(-1.976)$ & $(-4.586)$ & $(-6.627)$ & $(-0.527)$ \\
\hline \multirow{2}{*}{ Liquidity } & $-0.547 * * *$ & 0.0478 & $-0.582 * * *$ & 0.165 & $-0.148 * * *$ \\
\hline & $(-0.0981)$ & $(-0.626)$ & $(-0.0989)$ & $(-0.432)$ & $(-0.0217)$ \\
\hline \multirow{2}{*}{ Grow } & -0.000841 & $-0.00487 *$ & 0.000126 & -0.00871 & 0.0000616 \\
\hline & $(-0.00337)$ & $(-0.00249)$ & $(-0.00379)$ & $(-0.00624)$ & $(-0.000765)$ \\
\hline \multirow{2}{*}{ Tax } & $2.761 * * *$ & $-0.938^{*}$ & $3.111 * * *$ & $4.497 * * *$ & -0.0134 \\
\hline & $(-0.77)$ & $(-0.508)$ & $(-0.828)$ & $(-1.476)$ & $(-0.114)$ \\
\hline \multirow{2}{*}{ Industry } & $0.333 * * *$ & 0.137 & $0.332 * * *$ & $0.426^{*}$ & 0.022 \\
\hline & $(-0.0918)$ & $(-0.105)$ & $(-0.106)$ & $(-0.24)$ & $(-0.0244)$ \\
\hline \multirow{2}{*}{ Constant } & -22 & $85.19 * *$ & -27.49 & -49.2 & 2.914 \\
\hline & $(-47.36)$ & $(-35.07)$ & $(-53.44)$ & $(-86.35)$ & $(-7.657)$ \\
\hline R-sq & 0.101 & 0.1198 & 0.1082 & 0.139 & 0.0668 \\
\hline $\begin{array}{c}\text { Company } \\
\text { number }\end{array}$ & 890 & 132 & 758 & 448 & 466 \\
\hline
\end{tabular}

Note: \# high leverage ratio \#\# low leverage ratio

\section{Conclusions and policy recommendations}

This paper selects non-financial enterprises in Guangdong, Hong Kong and Macao from 2007 to 2017 as samples. It first analyses the characteristics of the leverage ratio in the greater bay area and conducts a comparative analysis. Then, it conducts empirical research on the macro and micro factors influencing the leverage ratio of enterprises using the two-way fixed effect model. The conclusions are as follows: The leverage ratio of non-financial enterprises in the Guangdong-Hong KongMacao Greater Bay Area is not high in comparison with that of similar enterprises 
in other regions of China and the world's major economies. From the perspective of ownership, the leverage ratio of state-owned enterprises is higher than that of nonstate-owned enterprises, with the central state-owned enterprises having the highest ratio, while foreign-funded enterprises have the lowest. From the perspective of industry, the leverage ratio differs significantly across industries. From the regional perspective, before 2008, the enterprises in Macao had the lowest leverage ratio, and those in Guangdong had the highest. In recent years, the corporate leverage ratio in Guangdong, Hong Kong and Macao has tended to be similar.

Corporate profitability is the most important micro-level influencing factor affecting the leverage ratio. Corporate profitability, tangible asset ratio and liquidity ratio have a significant negative impact on all non-financial enterprises in the greater bay area. Enterprise size has a significant negative impact on non-stateowned enterprises and enterprises with a high leverage ratio but no significant negative impact on state-owned enterprises. Asset turnover has a significant positive impact on low-leverage enterprises. The non-debt tax shield has a significant positive impact on non-state-owned enterprises and enterprises with a high leverage ratio. The median leverage ratio has a significant positive impact on state-owned and non-state-owned enterprises.

Economic growth has the most significant direct impact on the leverage ratio of non-state-owned enterprises. Improvement in the macro economy has a significant positive impact on the leverage ratio of non-state-owned enterprises and a positive but nonsignificant impact on state-owned enterprises. The policy uncertainty index has a positive impact at the significance level of $10 \%$ for state-owned enterprises and a significant negative impact on high- and low-leverage enterprises. The inflation rate and M2 growth rate have a significant negative impact on enterprises with a low leverage ratio.

The indirect influence of economic growth rate, M2 growth rate and policy uncertainty on the leverage ratio is significant. An increase in the economic growth rate and $\mathrm{M} 2$ growth rate strengthens the negative impact of the tangible asset ratio on the corporate leverage ratio. The M2 growth rate reflects the degree of easing of the credit market. When the M2 growth rate increases, the stock market becomes more dynamic, and enterprises with a high ratio of tangible assets have lower equity financing costs. When the stock market is favorable, enterprises prefer equity financing. The increase in the M2 growth rate weakens the negative impact of profitability on the leverage ratio, like economic growth weakens the negative impact of profitability and liquidity ratio on the leverage ratio. An increase in policy uncertainty strengthens the negative impact of profitability on the leverage ratio for state-owned enterprises and weakens it for non-state enterprises. Increased policy uncertainty also reduces the negative impact of enterprise size on the leverage ratio of non-state-owned enterprises.

In view of the above conclusions, this paper proposes the following policy suggestions:

(1) In the allocation of financial resources, the restrictions by type of enterprise ownership should be overcome, and state-owned enterprises should be further 
reformed. Among non-financial enterprises in the greater bay area of Guangdong, Hong Kong and Macao, those with high leverage ratios are state-owned enterprises, especially central state-owned enterprises. Therefore, the priority of "deleveraging" is to reduce the leverage ratio of central state-owned enterprises. We should speed up the merger and reorganization of state-owned enterprises with low output efficiency and high energy consumption to improve their production efficiency, utilization rate of financial resources and industrial competitiveness. In addition, we should actively promote the reform of mixed ownership, which will help reduce the asymmetric impact of economic policies on state-owned and non-state-owned enterprises.

(2) We should promote the development of a multi-level capital market and the construction of a bond market. First, we need to respond positively to national policies and build a diversified, international and trans-regional investment and financing system for scientific and technological innovation in the GuangdongHong Kong-Macao Greater Bay Area. Regulatory powers should be delegated to lower-level governments, and a multi-level investment and financing platform should be vigorously developed for the greater bay area. Second, we should standardize credit rating agencies and improve the information disclosure system to lay a good foundation for the companies' bond issuance. Finally, the pilot system of corporate bond registration should be promoted in the Guangdong-Hong KongMacao Greater Bay Area to reduce issuing costs and improve efficiency.

(3) We should be cautious about innovative financial instruments and guard against hidden debt risks of non-financial enterprises. We should pay attention to the hidden debt risk brought by financial innovative instruments (such as perpetual debt). Perpetual bonds are generally recorded into equity in practice. Therefore, the issuance of perpetual bonds by enterprises reduces their leverage ratio but in fact increases their hidden leverage and debt risk. The regulators of the GuangdongHong Kong-Macao Greater Bay Area should pay attention to the hidden leverage associated with such financial innovation tools, and rating agencies should fully consider such hidden debt to reduce the level of debt risk.

\section{ACKNOWLEDGEMENTS.}

The authors acknowledge the valuable comments and suggestions provided by our colleagues.

\section{FUNDING.}

This research is partially funded by Youth Project of the National Social Science Foundation of China (19CJY064) and Major Projects of National Social Science Fund (21ZDA115, 21ZDA044).

\section{DECLARATIONS OF COMPETING INTEREST.}

The authors declare that they have no conflicts of interest. 


\section{References}

[1] X. Tan, B. Yin and Y. Yang. (2018). "A study on determinants of Chinese nonfinancial corporation's leverage: 2002-2015," Journal of Central University of Finance \& Economics, no. 2, 2018, pp. 23-37.(in Chinese).

[2] Z. Xiao and H. Zou. (2008). "The determinants of capital structure and equity financing preference in listed Chinese companies," Economic Research Journal, no. 6, January, 2008, pp. 119-134+144.

[3] D. Su and H. Zeng, (2009). "Macroeconomic conditions and corporate capital structure: evidence from publicly-listed firms in China during 1994 and 2007," Economic Research Journal, vol. 44, no. 12, 2009, pp. 52-65.

[4] M. Belkhir, A. Maghyereh and B. Awartani. (2016). "Institutions and corporate capital structure in the MENA region," Emerging Markets Review, vol. 26, March 2016, pp. 99-129.

[5] J. Liang, L. F. Li and H. S. Song. (2014). "An explanation of capital structure of China's listed property firms," Property Management, vol. 32, no. 1, February 2014, pp. 4-15.

[6] Z. Lu, J. He, H. Dou. (2015). Peking University and Ji'nan University, "Whose leverage is more excessed, SOEs or non-SOEs?" Economic Research Journal, vol. 50, no. 12, 2015, pp. 54-67.(in Chinese).

[7] P. Guo and P. Sun. (2003). The industrial characteristic of capital structure: an empirical study on Chinese listed companies," Economic Research Journal, no. 5, 2003, pp. 66-73+93.(in Chinese).

[8] L. Li and S. Z. Islam. (2019). "Firm and industry specific determinants of capital structure: evidence from the Australian market," International Review of Economics \& Finance, vol. 59, no. 3, January 2019, pp. 425-437.

[9] Köksal, B., Orman, C. (2015). "Determinants of capital structure: Evidence from a major developing economy," Small Bus Econ, vol.44, 2015 pp.255282.

[10] W. Chen and Q. Xiong. (2017). "The international comparison of leverage rate of China's non-financial enterprises and suggestions," Studies of International Finance, vol. 2, 2017, pp. 3-11.(in Chinese).

[11] M. Halling, J. Yu and J. Zechner. (2016). "Leverage dynamics over the business cycle," Journal of Financial Economics, vol. 122, no. 1, October 2016, pp. 21-41.

[12] J. Liu, D. Chen and N. Xu. (2018). "Has "low growth, low inflation" driven the rapid rise of China's macro-economy leverage ratio," Journal of Jiangxi University of Finance and Economics, no. 4, 2018, pp. 13-23.(in Chinese).

[13] P. Rao, H. Yue and G. Jiang. (2017). "Economic policy uncertainty and firms' investment," The Journal of World Economy, vol. 40, no. 2, January 2017, pp. 27-51.

[14] Y. Ji, X. Wang, Y. Tan and Y. Huang. (2018). "Economic policy uncertainty, implicit guarantee and divergence of corporate leverage rate," China Economic Quarterly, vol. 17, no. 2, 2018, pp. 449-470. 
[15] W. Li, C. Yu and H. Wu. (2017). "Systemic financial risks and soft budget constraints," Southeast Academic Research, no. 6, 2017, pp. 65-77+247.(in Chinese).

[16] Z. Xiao. (2005). "Research on influencing factors of capital structure of listed companies in China," Chinese Financial \& Economic Publishing House, 2005.(in Chinese). 